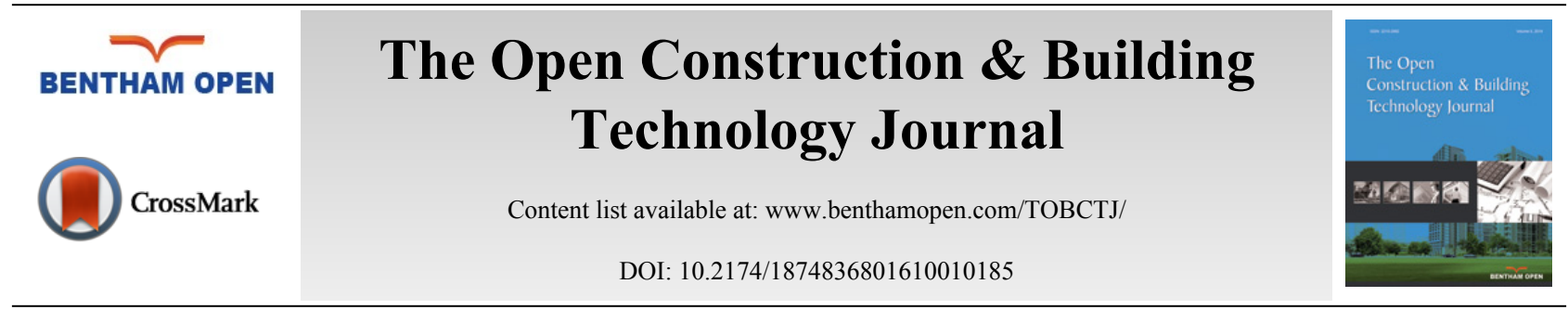

\title{
Retraction Notice: Sensitivity Analysis on Stability Parameters in Landfill
}

Sun Hong-Jun*, Fan Yan-Chao and Zhao Li-Hong

College of Civil Engineering \& Architecture, Liaoning University of Technology, Jinzhou, Liaoning 121001, China

\section{RETRACTION}

The Publisher and Editor have retracted this article [1] in accordance with good ethical practices. After thorough investigations we believe that the peer review process was compromised. The article was published online on 19-08-2015.

\section{REFERENCE}

[1] S. Hong-Jun, F. Yan-Chao, and Z. Li-Hong, "Sensitivity Analysis on Stability Parameters in Landfill", Open Constr. Build. Technol. J., vol. 9, pp. 108-111, 2015.

(C) Hong-jun et al.; Licensee Bentham Open

This is an open access article licensed under the terms of the Creative Commons Attribution-Non-Commercial 4.0 International Public License (CC BY-NC 4.0) (https://creativecommons.org/licenses/by-nc/4.0/legalcode), which permits unrestricted, non-commercial use, distribution and reproduction in any medium, provided the work is properly cited.

* Address correspondence to this author at the College of Civil Engineering \& Architecture, Liaoning University of Technology, Jinzhou, Liaoning 121001, China; Tel: 13304062944; E-mail: Sunhongjun_2006@163.com 